\title{
Supranational identities in planning
}

\section{Abstract}

This paper studies how different kinds of regional identities (cultural, strategic and functional) are intertwined in supranational planning processes. By using Cascadia in North America and Barents in Europe as examples, it is shown that although the significance of identity is relatively unclear, territory-network interplay contributes to the idea of (bounded) regions and regional identities. Issues related to territorial symmetry and inclusion/exclusion indicate that while territory has its allure, identity can also emerge within softer, fuzzy spaces with several simultaneous demarcations. Although strategic and functional identities are emphasized in contemporary (soft) planning, elements of cultural identity can be observed, too.

Keywords: Identity, planning, Cascadia, Barents.

\section{Introduction}

Recent years have witnessed increasing supranational integrations as new cross-border regions have been established in Europe and elsewhere. According to Söderbaum (2005), security motives were more prominent in cross-border regionalism during the Cold War, whereas "today it is widely held that cooperation and integration across borders can create opportunities for economic growth" ( $p$. 101). Although the aim of reducing political tensions has not completely disappeared, the shift from geopolitics to geoeconomics (Moisio and Paasi 2013) can be clearly observed, denoting that newly conceived supranational spaces are expected to serve as engines of economic growth par excellence. This transformation is closely linked to 'new regionalism', with its origins in spatial economy, and the notion that functional systems have increasingly escaped the politico-administrative frame of nation-states. This has meant that actors can now operate within the 'new' spatial levels beyond state borders. Although borders have not altogether disappeared, they have become "more porous and flexible" (Keating 2008a, p. 630), enabling new spatial configurations to emerge. Relatedly, new regionalist literature has approached regions from a constructivist perspective, underlining regions not as 'pre-given' but as political and social constructs both intentionally and unintentionally made and unmade, devised by human actors to either protect or transform existing structures (Söderbaum 2016, p. 6).

Regional identities have been typically linked with nation-building practices, as most states have promoted a sense of homogeneity and singular identity (Slocum and Van Langenhove 2005). Currently, however, the 'identity-work' has been increasingly rescaled to macro- and micro-regions (see Söderbaum 2005) above and below the state, and, for example, on the European scale the idea of Pan-Europeanism has been linked to the European project. According to Popescu (2012), it is typical that state stakeholders deploy identity-discourses to present supranational regions as cohesive spaces. This means that there is a need to make such spaces visible to their publics in order to gain acceptance, presumably much to the activities of regional elites. However, as Popescu (2012) continues, there is little evidence that cross-border identities have emerged within the wider audiences. As they are often top-down constructions of the regional elite, serving primarily economic and business aspirations, supranational regions have in many cases remained 'soft spaces of governance' or 'regions on paper' and thus relatively unfamiliar and meaningless to their 
inhabitants. They are often merely map-and-pencil delimitations, and practically non-existent for most people, the planning and development circles (i.e. those who have the map and pencil) excluded.

The aim of this paper is to study how supranational regional identities are linked to and embedded into agency and practices in planning. The focus is on how the various actors and institutions in planning understand and possibly nurture the idea of regional identity. In addition, supranational identities are studied in relation to the various understandings of space, and the distinction between relational and territorial spaces in particular. Relatedly, this research touches also on the ideas of soft planning and soft spaces, an approach relatively dominant in current planning agendas as well as in planning research. By using the supranational regions of Cascadia in Northwest USA and Southwest Canada, and the Barents Euro-Arctic region in northernmost Europe as examples, this article aims to highlight how relatively newly conceived supranational spaces are shaped by various institutions and advocates through practices of soft (and occasionally some harder) planning and more precisely - how these planning practices contribute to an identity that is more or less territorial. The aim is thus to highlight the interplay of supranational regionalism and identity through emphasizing the key 'modes' of agency in planning. A more general goal of the article is to gain a better understanding of the dynamics and interplay of cross-border co-operation and identityformation. Three fundamental components of this study are 1) agency, 2) identity and 3) planning, each of which becomes discussed throughout the paper.

The context of this paper is well suited to address the divide between the discourse of macroregionalism (i.e. the large territorial units between the 'state' and the 'global' level) and the discourse of micro-regionalism (i.e. between the 'national' and the 'local' level). As Söderbaum $(2005 ; 2016)$ puts it, whereas macro-regions are typically unions and alliances of nation-states (e.g. the EU), micro-regions have perhaps too often been seen as consisting of sub-national regions within the territorial boundaries of particular nation-states. This paper, for its part, underlines that the conventional distinctions between macro and micro, between international and domestic, and between state and non-state need to be less rigid. Also, this paper highlights that a 'planning region' is not unrelated to issues of culture and identity (cf. Söderbaum 2005, p. 94), and that the link is actually deserving of further attention. It also discusses supranational regionalism in terms of its interplay and tensions with the existing territorialities of nation-states.

The paper discusses next the key concepts in more detail. The most essential concept, identity, is studied through identifying three kinds of (regional) identities: cultural, geo-strategic and functional. After the comparative empirical analysis ${ }^{1}$, conclusions are presented.

\section{Key concepts and research questions}

\section{Agency}

As regionalism is approached here as a process, agency is placed on the forefront. This study distinguishes two forms of agency and makes an analytical and methodological distinction between

\footnotetext{
${ }^{1}$ The analysis discusses both regions together through the key concepts and forms of identities. This approach was chosen to better tease out the different understandings and approaches on supranational identities in different, yet to some extent similar regional constellations and planning cultures.
} 
activists and advocates, focusing on the latter. This distinction is useful for understanding how different actors and social positions are significant not only for the production of regions, but also for the meanings or 'identities' associated with them. Advocates are crucial actors in what Paasi (2010) labels 'soft region work', a mode of planning and development that has much resemblance to the idea of soft planning and soft spaces (Haughton et al. 2013, Walsh et al. 2012). The power of advocates emerges from their institutionalized positions, which have continuity. Activists, on the other hand, are actors who participate in an active struggle (often via regional movements) over specific meanings which they conceive of as 'regional'.

As supranational regions are typically top-down by nature (Hall 2008, Fawn 2009), this study focuses also on 'institutional design' (Söderbaum 2016), i.e. how supranational identities become constructed by the various institutions wherein the advocacy lies. This is done through an analytical distinction between instrumental and identity-providing institutions. As originally outlined by Blatter (2004), this conceptualization starts with the assumption that institutions are created to serve specific purposes and that there is an interdependence between regional actors. The instrumental dimension sees institutions as mechanisms of control, whereas the identity-dimension emphasizes 'symbolic activity' and 'ritual representations' that create mutual obligations among the group members. Thus, the former focus on the establishment of norms and rules, whereas the latter rely on emotional symbols for mobilization. These two dimensions are also naturally somewhat complementary and often fulfilled to some extent by every political institution. However, although constructed simultaneously through various actor networks, they are not totally commensurable.

Identity

A fruitful option to conceptualize regional identity and its meanings is to apply van Houtum's and Lagendijk's (2001) key ideas of three identities. Essentially, they argue that polycentric (crossborder) regions have cultural, geo-strategic and functional identities, all of which interact and are more or less consciously produced to serve the interests of dominant actors. Of the three dimensions, the strategic identity refers to processes in which regions and their identities are strategically shaped, through mapping in planning documents, for instance. In this context, geographical configurations are shaped (and mapped) in strategies to serve networking, which is regarded as fundamentally growth-simulating and good.

The other two dimensions, cultural and functional identity, are simultaneously linked to the idea of spatial cohesion and connections, albeit with different emphasis on territories and networks. Cultural identity refers to the cultural us-and-them divisions that are caused by the collective consciousness of belonging and othering. Fundamental in this is naming (cf. Paasi 1986), but maps have a crucial role too, for they are 'an expressive and vigorous form of geo-strategy that invoke rather than interpret' (van Houtum and Lagendijk 2001, p. 753). This relates to demarcation practices, where distinctions between 'us and them' are made. Also, the creation of us and them is both a precondition for the shaping of strategic capacity and an asset in shaping objects of strategy making. This means that cultural elements can be utilized in image-building and in various promotion practices to boost the region and to create competitive edge through differentiation. Cultural identity is thus not merely a historical sense of belonging but also instrumental. Functional identity brings out the issues of demarcation and coherence and stems from various linkages 
between the nodes and hubs. Functionality can be genuine so that the links and ties can be measured and verified, but also intentional as is the case in drawing gateways, growth corridors, etc. on the map, for instance. As van Houtum and Lagendijk (2001) put it, drawing lines around and arrows between hubs simplifies reality, much in the sense of inclusion and exclusion. If functional identity exists only in maps and other representations, territorial cohesion may remain weak. Also, when the functional region is effected through demarcation, it can create political tensions by contradicting prevailing regional structures. The idea of employing soft spaces is one way to avoid this, as fuzzy boundaries do not mark definite lines of inclusion and exclusion.

Taken together, regional identity has certain values and functions in planning, especially as planning increasingly emphasizes (and constructs) new competitive spaces that often cross the borders of nation-states. Typically, regional identity, particularly when understood as regional consciousness, has been considered a 'soft tool' in planning, something that - as a collective idea of a distinct region - supports regional cohesion, commitment and co-operation (Tewdr-Jones and Allmendinger 2006, Haughton and Allmendinger 2015). Alternatively, when understood as the characteristics of a region, regional identity has become associated with regional branding. Whereas the latter connects identity more clearly with the economic sphere of regional development and planning through inter-regional competition of flows, the significance of regional consciousness seems to be less clear. Despite being seen as somewhat beneficial, the regional elite seem uncertain as to what it is actually good for, or why or how it should be strengthened. Many advocates feel that newly conceived regions should be better familiarized to wider audiences, yet do not know why and especially how this might be accomplished (Zimmerbauer 2014).

Although the role and meaning of regional identity is largely unclear in planning and development, its significance should not be downplayed. On the contrary, it should be better acknowledged. As Keating (2014) states, "in regions with strong popular identities, institutions based on these may carry a greater legitimacy" (p. 242). This is to say that non-standard regions (cf. Deas and Lord 2006) may simply disappear if they are familiar to few people (typically planning and administration professionals) and little collective regional identity is attached to them. This represents a utilitarian way of approaching identity, as it is closely related to the legitimation of regional advocates and their respective institutions. In this context, the interplay of identity and branding needs to be emphasized as well, for often the 'imagined communities' (Anderson 1991) are created by promotion just to show power centres that the region exists and deserves to be funded. However, regional identity also feeds into regional initiativeness. It can be claimed that without a sense of belonging - a key element of regional identity - there can be neither cohesion nor co-operation for the region. Regional identity creates active citizenship that can be highly supportive of the dominant planning agenda, yet at times it can also make people resist prevailing ideologies, as has been seen in cases where regions are threatened by top-down deinstitutionalization.

It is of course perfectly appropriate to ask whether the new supranational spaces of flows, or 'soft spaces' (as e.g. Allmendinger et al. 2014 put it), are even meant to survive or require an identity. Perhaps it should be accepted that they are ad hoc constructs of (and for) the regional elite to create short-term added value for 'participants' rather than inhabitants, and that they were never meant to exist beyond the objectives or programmes they were created by. Accordingly, are not all regions 
social constructions that may become deconstructed as quickly as they were constructed, or are just as likely to fail as to succeed (cf. Söderbaum 2016)? While the question whether they should survive is essentially political and contextual, and beyond the scope of this paper, it is nevertheless clear that without regional identity non-standard regions will disappear rather quickly when the political agenda changes. While this may not be any problem for the inhabitants in general, it is something the regional elite engaged in planning and development should heed well. After all, the resources that are used to institutionalize the region would be wasted if the region were to become deinstitutionalized - at least the money used to make the region familiar to wider audiences. Thus, while it is acknowledged that identity is not something all regions automatically have, it is of use if continuity of region (and regional institutions) is aimed at.

\section{Planning}

In order to understand the role of identity in planning, it is important to examine both the institutions that generate identity and the processes of planning wherein identity becomes manifested or constructed. Analytically, this denotes a need to distinguish not only the (instrumental and identity-providing) institutions, but also the different 'modes' of planning. Here, the distinction between soft and hard planning is useful. Generally, soft spatial planning refers to planning through informal means. As Walsh et al. (2012) put it, soft spatial planning refers to a type of planning that is not grounded on legal or financial instruments; it refers to informal ways of acting and to joint visioning and strategy making. Relatedly, soft spaces can be defined as 'particular strategy-making episodes, where strategic spatial planning moves beyond formal planning arenas in attempts to destabilize existing practices and structures' (Olesen 2011, p. 151). This means extending the idea of soft spaces to planning processes, beyond merely the way space is understood. As Walsh et al. note, it is unclear whether soft planning, based on soft, informal governance, always involves soft spaces. This means that the connection between soft planning and soft spaces, as well as between formal planning mechanisms and 'hard' spaces, is rather unclear.

Whether planning and spaces are soft or hard has much to do with regional identity. As noticed, soft spaces with fuzzy boundaries are often made by and for the regional elite for specific purposes, and identification with them can remain weak. Hard planning refers to formal planning mechanisms, which means that it is centred on territorial spaces, as, particularly in hard planning, planners often operate in established administrative structures that tend to have clear spatial borders for the powers they exercise. Hard spaces, with clearer delineations of inclusion and exclusion, are generally more useful for identity-construction, as us-and-them divisions are the building blocks of regional identity. Thus, hard planning can be seen as a practice of hardening 'regional spaces' (see Jones and MacLeod 2004), hence contributing to regional identity as a sense of collective regional consciousness. However, both soft and hard spaces can be merely 'regions on paper' and being either or as such guarantees that regional identity exists. As Metzger (2013) puts it, regional identities travel, and, although they also stick, do not necessarily require a politico-administrative territory as a backbone.

Yet, the connections between soft planning and soft spaces, as well as between formal planning mechanisms and hard spaces, can be teased out by using the concept of identity as a tool. When using this approach, hard spaces with rather clear boundaries should not be automatically linked to 
formal planning, as soft planning can take place in hard spaces. Also, soft planning can lead to hard spaces if driven by a strong sense of territoriality and identity. Similarly, hard, formal planning has difficulties to promote soft spaces with fuzzy boundaries if territorial consciousness is strong to begin with. Quite the opposite, the planning process is likely to further strengthen the regional identity through various manifestations of the region in question.

It should also be noted, that although 'softening' and utilizing more relational vocabulary (as opposed to territorial) can be a technique to depoliticize planning and to avoid territorial disputes, soft spaces and/or fuzzy boundaries are not as such fundamentally less political than clearly demarcated hard spaces. On the contrary, due to their vagueness, soft spaces can be as (if not even more) contested and controversial than hard ones, which usually have a juridical layer embedded in their borders. As Keating (2008a) relatedly observes, it is those undisputed and unchallenged borders that have become more porous. Conversely, this implies that disputed borders have a tendency to harden.

To draw together the approach on the key concepts and to clarify the analytical framework two research questions can be formulated. They are 1) how the agency in planning is centred on instrumental and identity-providing institutions, and 2) how supranational identity becomes constructed in planning by those actors, as seen through the analytical distinction between strategic, cultural and functional identities. In the analysis that follows, the focus is thus on the identitycreating processes that are managed by institutions that have a key position in developing the case study regions.

The empirical data consists of two different bodies. First, six interviews were conducted in Cascadia during September and October 2014 and eight in September and October 2016 in Barents. The interviewed persons were key advocates in planning and research, representing organizations such as regional councils, development agencies, research organizations, county administrative boards and other public-private governance institutions. Second, the first research question is approached through document analysis. The analysed documents serve as a secondary dataset and include: 1) four joint statements of the Barents Euro-Arctic Council (2000, 2001, 2011 and 2013), and 2) four Pacific Northwest Economic Region's action items (2006, 2011, 2012 and 2013).

\section{Case study regions and key actors}

This section discusses the case study regions, the key features of which are summarized in Table 1. Despite of their unique features, the regions have much in common, such as current key actors and a degree of peripherality. Also, despite of their different origins, both have lately become manifested through the vocabulary of geoeconomics. Basically, the case study regions were chosen on account of their similarities and dissimilarities, both of which are studied here in more detail together with the rationale of comparability. 


\begin{tabular}{|l|l|l|}
\cline { 2 - 3 } \multicolumn{1}{c|}{} & \multicolumn{1}{c|}{ Cascadia } & \multicolumn{1}{c|}{ Barents } \\
\hline Orgins in & $\begin{array}{l}\text { Environmental movement, } \\
\text { bioregionalism, ecology }\end{array}$ & $\begin{array}{l}\text { Post-Cold War geopolitics, } \\
\text { Norway-Russia relations }\end{array}$ \\
\hline Emerged in & 1970s (as a bioregion) & $\begin{array}{l}\text { Officially in 1993 (Kirkenes } \\
\text { Declaration) }\end{array}$ \\
\hline Key actors & $\begin{array}{l}\text { NGOs, trade and economic } \\
\text { organizations }\end{array}$ & $\begin{array}{l}\text { States, sub-state regions (later: } \\
\text { trade associations) }\end{array}$ \\
\hline Degree of peripherality & Medium & High \\
\hline $\begin{array}{l}\text { Geopolitics/geoecomics at } \\
\text { the fore }\end{array}$ & Geoeconomics & Both \\
\hline $\begin{array}{l}\text { Unique features } \\
\text { Disparities within the region } \\
\text { (social/economical/political) }\end{array}$ & $\begin{array}{l}\text { Seattle/Vancouver high } \\
\text { tech cluster, 'green tech' }\end{array}$ & NATO-Russia militarized border \\
\hline
\end{tabular}

Table 1. Key features of Cascadia and Barents

\subsection{Cascadia}

Cascadia overlaps the border of the USA and Canada in the west (Picture 1). According to Smith (2008, see also Brunet-Jailly 2008) the initial idea of Cascadia emerged in the 1970s and 1980s. It was originally an environmental concept and referred to an area of Pacific Northwest North America between the Cascade Mountains and the Pacific Ocean. The initial Cascadia included parts of seven jurisdictions (Northern California, Oregon, Washington, Idaho, Western Montana, British Columbia and Southeast Alaska), yet Cascadia was seen to transcended political and even geographical definitions: David McCloskey, founder of the Cascadia Institute, emphasized Cascadia as an ideological notion with the environment at its centre. Later Cascadia has changed from bioregion to economic region, with the help of organizations such as the Pacific NorthWest Economic Region (PNWER), which was introduced in 1991. At that time, the number of subregions diminished to five, encompassing the states of Washington, Idaho, Oregon, Montana and British Colombia. In this iteration Cascadia has a population of over 16 million (Sparke 2005).

Cascadia is characterized by low socio-economic interdependencies (Sparke 2000) and comparatively similar political systems and cultural values (Brunet-Jailly 2008). According to Sparke (2005, p. 67), the region has lately served as a site for neoliberal experimentation, and keywords such as freedom, welfare, rights and sovereignty have been rearticulated in terms of neoliberal resonances. Thus, the eco-logics of the bioregional vision were 'effectively appropriated into the eco-nomics of the neoliberal Cascadia' (p. 69). This has transformed Cascadia into a fluid, evolutionary and 'quite plastic notion capable of morphing into different shapes and sizes according to the particular needs of particular "practical” visions' (Sparke 2000, p. 7). Accordingly, the emphasis on territorial policy-making is rather weak, and cross-border networks of interaction are distinct from but complementary to formal federal government ties. They represent goal-oriented, problem-focused networks working across varied spatial scales. Typical of North American supranational regionalism, Cascadia has many cross-border coalitions, some of which compete against each other. Moreover, indicating the different paths of regionalism in Europe and North America, the institutionalization of Cascadia was the result of the strong influence of private and 
non-profit actors that promote no clear-cut territorial demarcations and are limited in their functional scope (Blatter 2004).

In addition to the PNWER there are other organizations promoting and developing the Cascadia region. For example the Cascadia Project, a public-private initiative which was established by leading politicians and academics, has focused on transportation, trade, tourism and technology in the Vancouver-Seattle-Portland corridor. In addition to economic growth-promoting structures there have also been coalitions with more environmentalist agendas. Looser social movements include Cascadia Now and Cascadia Institute, both of which actively promote the idea of Cascadia as a bioregion (Blatter 2004, Brunet-Jailly 2008).

\subsection{Barents}

The history of cross-border co-operation between 'east' and 'west' in northernmost Europe dates back to the Pomor trade era of the early 19th century, but the Barents Euro-Arctic region was officially established in 1993, when the Kirkenes Declaration was signed by the member states, after strong Norwegian initiativeness. The creation of the Barents Region is closely linked to the end of the Cold War and the new possibilities for supranational co-operation. These opportunities stemmed from two large federative processes: the enlargement of the EU and the dissolution of the Soviet Union (Elenius 2015). In short, the region was designed to promote political stability and economic prosperity, "its purpose enshrined in the concepts of normalization, stabilization and regionalization" (Elenius 2015, p. 420). In more exact terms, the purpose of co-operation has been to strengthen east-west infrastructure, establish people-to-people contacts and thereby contribute to the cultural and social, but increasingly also economic development of the region. The focus has been rather broad, since the aim has been to develop interregional exchange in fields of culture, indigenous peoples, youth, education, trade, environment, transportation and health.

Presently the Barents Region consists of 14 sub-national regions in Norway, Sweden, Finland and Russia. The population living in this region is about 5230000 (Barentsinfo 2016). The Barents Region is unique for its location in what was once a potential scene of military conflict between east and west. The high east-west border originates from the pre-Soviet era, and is still highly visible (Zimmerbauer 2016). Differences between the Nordic countries and northwest Russia exist in many spheres of life, as over centuries the Nordic people have merged together culturally, politically and economically, and Russia has followed its own path in history (Elenius 2015). Although a degree of polarization cannot be denied, this vast region also shares many features, including peripherality and low population density (Svensson 1998).

Whereas in Cascadia the key actors are typically non-state, emphasizing 'soft' regionalism, the Barents initiative was envisaged from the very beginning as a two-level structure of both state and non-state actors. First, the Barents Euro-Arctic Council (BEAC) is the main forum for intergovernmental co-operation. The members of the BEAC are foreign ministers. Second, the Barents Regional Council (BRC) unites regional representatives, e.g. the county governors of all 14 member sub-regions. According to Hasanat (2012) the Regional Council has objectives and operations similar to those of the BEAC, and councils clearly have overlapping identities. In addition to these governance bodies, a number of working groups have been established by the $\mathrm{BEAC}$ and the BRC to deepen co-operation on relevant issues, such as energy, tourism, healthcare, 
economic co-operation, transportation and indigenous peoples. Six of the working groups are jointly managed by the BEAC and BRC.

At present, the aim of ensuring stability and security in the region has been complemented if not replaced by the aim of improving economic networking and business opportunities, especially in the fields of tourism, energy and trade. This has increased the number of small-scale, bilateral and locally funded initiatives, and brought in many new actors, such as chambers of commerce, consulting enterprises and other trade organizations. These operate either without the involvement of formal administrative organizations or, more typically, closely linked to regional administrative bodies (Zimmerbauer 2016). Geoeconomization is by no means unique to Barents but can be identified in Cascadia and in many other cross-borders regions as well. It is both the reason for and outcome of the increase in relational, network-emphasizing discourse in planning.

\subsection{Rationale of comparability}

As said, the regions have many similarities, which makes a comparative approach fruitful. Common features include unfamiliarity to wider audiences, vagueness of territorial setting, efforts in branding, and relatively thin regional identities. Both regions also share a sense of historical alienation from faraway state capitals and power hubs and therefore display a distrust or reservation with respect to the national governments (Sparke 2005, 70). Both regions also reveal the increasing role of competitiveness in supranational integration: they are currently becoming increasingly characterized by cross-border trade and economics. In fact, regional trade agreements, as a form of inter-state arrangement, have the paved way for much cross-border co-operation in both regions. The Canada-US Free Trade Agreement (together with NAFTA) and the Partnership and Cooperation Agreement between the EU and Russia are just some examples of such treaties. Even though it can be claimed that some of the agreements embracing the idea of multilateralism (and the WTO's ontologically positive view of globalization and market forces fostering open societies) have been inefficient and have therefore been replaced by bilateral ones (cf. Söderbaum 2016), there is concomitantly an abundance of various kinds of regional trade arrangements - engaging multiple actors and regions of all scales - that contribute to supranational regionalism within and around Cascadia and Barents. Of course the future will tell if the situation changes, not least because the current tensions and sanctions between the EU and Russia have again brought geopolitics back onto the agenda in the European north. As Cowen and Smith (2009) state, the 'logics' of geopolitics and geoeconomics are different, and although "the rise of geoeconomics does not necessarily mean that boundaries and territories become less important” (p. 43), they entail different articulations and embrace different processes, sometimes resulting in 'geographical conflicts'.

The comparative approach is also justified due to the regions' variety of dissimilar borders as well as differences in institutionalization. As for institutionalization, not only does the role of supranational institutions vary between the regions, but also the input of the nation-states themselves differ, suggesting different orientations of emphasis between cross-border 'politics and business' (cf. Svensson 1998). In Europe, supranational integration has been supported and driven by supranational institutions (namely the EU) and other (regional) public representatives, whereas in North America it has typically been orchestrated by private and non-profit involvement (Blatter 
2004). This is to say that despite the top-down nature of regionalization in both regions, it is more observable in the Barents region.

The peripheral character of the Barents region in particular adds a certain uniqueness compared to the current research agenda, where much emphasis has been placed on metropolitan cross-border networks and regions (e.g. Perkmann 2007, Hall 2008), or alternatively on states and macro-regions consisting of states. By highlighting both state and non-state agency as well as spatial power symmetries/asymmetries in a regional context, but also stepping away from the conditions provided by the EU, this study resonates with and contributes to topical themes in International Relations studies (Fawn 2009), addressing some of its pitfalls: methodological nationalism, taking regions as pre-given and focusing merely on single cases (Söderbaum 2016).
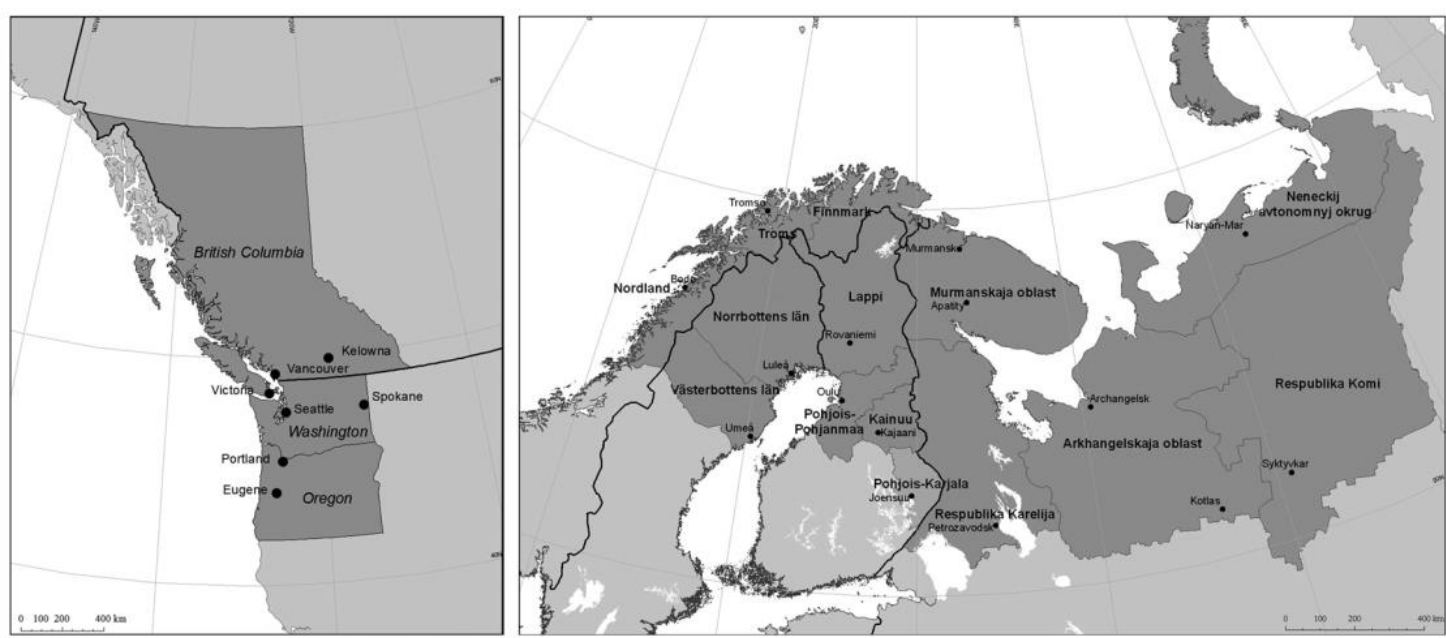

Figure 1. One delineation of Cascadia (left) and the Barents Euro-Arctic region (right)

\section{Agency and identities in planning}

It can be argued that Cascadia is more of a governance-type constellation, whereas Barents has more traditional government structures. In Cascadia, organizations such as PNWER serve as a platform for fluid, public-private networks that are often constructed for single purposes. This means that partnerships across the border are constituted simply to solve regional problems that block cross-border flows or other issues requiring actions beyond the nation-state.

Cascadia is amorphous. There are several Cascadia organizations and they all participate in PNWER. There is a Cascadia transportation organization, there was a Cascadia institute in BC [...]. So, in terms of governance, having something, in PNWER's case, we have support from every jurisdiction, and from the private sector. It's a public-private partnership that's been successful. [Cas1: public/private nonprofit representative]

Our whole focus is bringing regional solutions. It's the process of bringing the right people to the table, looking at what are the goals, what's the problem and how do we solve it, and then bring those solutions to Washington DC and Ottawa. [Cas2: research institute rep.] 
The case is somewhat different in the Barents region, where the co-operation is more centred on the administrative circles. This is not to say that private-public and private-private partnerships are lacking in the Barents region, but to underline that the co-operation has been traditionally orchestrated by regional and national advocates and officials more than in the case of Cascadia. As to identity, this fact has no significant difference: as long as the grassroots activism is low, the strategic identity precedes the cultural one.

The attachment to official state structures provides an interesting approach to the question of peripherality and identity. As the quotations below illustrate, some parts of peripheries are more closely tied to the power-structures of nation-states, which causes difficulties in establishing governance structures especially in terms of public-private partnerships.

Almost all of the international activities must be approved by Moscow. The regional authorities and leaders in Russia have been very careful and circumspect. Yes, they have attended the meetings, but in fact they have been attending because there has always been some big guy from Moscow, too. And if Moscow shows the green light, then the negotiations can proceed very smoothly [...]. They are completely under Moscow's rule, in decision-making, these regions. So they must have the whole decision-making chain secured. [Bar1: regional council official]

We are on the edge, and when you are on the edge, no one pays attention to you. So that's why we have to do everything ourselves. We just go ahead and do it. So this region [Cascadia] has seen itself as being outside of the mainstream. [Cas2: research institute rep.]

Barents and Cascadia are both regarded as peripheral regions, yet differently. While both are located far from the 'power centres', Barents is nevertheless relatively closely tied to the state apparatus, especially in Russia. This situation causes power asymmetry, although the states have orchestrated much co-operation in the Nordic countries as well. In Cascadia, the location 'outside of the mainstream', relatively unattached to Washington DC and Ottawa, has, according to the interviewed advocates, been important in terms of a kind of 'cultural mindset'. This, in turn, has contributed to a notion of regional identity that has some cultural elements in it. In Cascadia, this kind of identity is based on the idea of being ecologically different and more progressive. As one interviewee put it, this is related to the region's leading position in green energy "and all the green stuff", but also to the "Seattle-Vancouver kind of high-tech culture and lifestyle". Thus, supranational identities stem not only from their location and connectedness with central authorities, but also from their local operating cultures in planning and governance practices. Accordingly, remoteness from the administrative hubs does not mean being excluded from innovation and economic networks.

Whereas in Cascadia the solutions to problems are made locally and then brought to central authorities, in Barents the incentives are more often top-down, coming from the central governments or national business organizations. The initiativeness of the nation-states and national organizations can be partly explained by geopolitical sensitivity and the initial need to reduce tensions between 'east' and 'west'. However, it also evidences that many of the region's functions are outlined from the outside, and that it serves as a 'laboratory' of supranational geopolitics and 
geoeconomics. As a supranational space orchestrated not only by the (sub)regions, but to large extent by the nation-states and the EU, much emphasis is placed on strategic identity, as it contributes to both spatial cohesion and competitiveness. At the same time, the idea of bounded territory becomes solidified. In Cascadia, functional identity seems to have more relevance, which is purportedly one reason for the more amorphous cross-border space.

In the context of soft/hard spaces and planning, the interplay of territorial and network-oriented approaches needs to be stressed. In Cascadia, the networks have not had a 'territory effect' (Painter 2010) to the same extent as in Barents, where the questions of inclusion and exclusion have been more relevant, or at least more politically sensitive. The case of North Karelia ${ }^{2}$ illustrates well that there has been much debate about which sub-national regions should be included in the Barents region. In Cascadia the many delineations co-exist in a manner that has restrained any desire to demarcate the region exhaustively. Thus, Cascadia can be described as a 'penumbral region' in the sense that it gets different territorial definitions depending on the context, and some boundaries are visible only 'when the light is cast from a certain angle' (Paasi and Zimmerbauer 2016). This stems from the fact that the co-operation is primarily about solving issues related to the border and territorialization processes subordinate to that. In Barents, the territorial approach to regionalization has been prioritized more, and it is not uncommon that networks are forced to follow the territorial boundaries. In this case, it is more the idea of a territory that creates the networks than vice versa. As the case of North Karelia province showed, a (sub)region can be excluded even if it has good networks across the border(s), if its inclusion is thought to cause territorial asymmetry. Thus, the question of symmetry/asymmetry is related not only to power but also to space and territorial setting.

I think that's what made Cascadia, from a policy point of view, interesting, because there have been some successes over the years in pushing these kind of reforms to make the securitized border less of a problem. [Cas3: public sector official]

We prepared the motion for North Karelia's membership in a meeting in Kuusamo... but the Norwegians opposed it so much [...] And I think that it is in fact a question of symmetry, which is linked to the power-structures, how the regions have power in relation to each other. But "arcticness" was the criteria that they used, to not expand [the region] too far south. [Bar2: regional council official]

This indicates that the idea(l)s of soft planning/spaces and 'open regionalism' (cf. Fawn 2009) are at the forefront in Cascadia. However, it would be untrue to say that Barents is merely about hard planning within the framework of hard space. Rather, while the territorial approach, with its questions of inclusion, exclusion and territorial power-symmetry, is stronger in the Barents region, the vocabulary of neoliberal soft planning is almost as relevant there as it is in Cascadia. Thus, it is highly important to point out that even though the origins of these supranational spaces are different, they are both currently deeply embedded in the dominant hegemonic neoliberal planning

\footnotetext{
${ }^{2}$ North Karelia first applied for membership in the Council in 1997, but faced opposition, mostly from Norway. One main argument was that no Nordic country should have more (sub)regions than the others. The debate led to a compromise in which North Karelia joined Barents as an observer member (Zimmerbauer 2014). After years of negotiations, the Barents Regional Council approved the full-fledged membership of North Karelia in November 2016.
} 
agenda with growing emphasis on competitiveness. However, as can be seen below, there is a concern that much of the economic co-operation in the Barents region might come to a halt due to the recent geopolitical tensions between the EU and Russia.

The only thing that the federal government really understands, when you talk about the relationship between security and facilitation of economic mobility, is competitiveness, building the economy, making the region more competitive, making the continent more competitive. And that's why business actors are important allies in this process. In some cases they drive the process. [...] And every time they have a summit, they work hard to get business people to come, because they know that government listens to the businesses, because of competitiveness. [Cas4: research institute rep.]

I think the added value of Barents comes down to the idea of its being an economic region. Barents has the strongest, clearest and most well-proven possibilities to be highly important domain in utilizing natural resources... it has the potential to do that. If we think in terms of economic regions, I can say that Barents is deeply intertwined with that kind of logics. [...] [And in 5-10 years] the business side can be even stronger, it can do really well, if some mega-projects or big infrastructure projects get on their way. [...] But if this geopolitical situation becomes even more tense, the cooperation might end. It may just end in the sense that it freezes. And this is completely possible scenario. [Bar3: trade organisation executive]

The emphasis on competitiveness contributes to territory-network interplay and realigns it. In the case of Cascadia, geoeconomization has tended to increase its softness, as institutions that are primarily instrumental have had a key role in the planning. In Barents, the situation is slightly different, as the introduction of soft planning has created the need for territorial redefinitions and redelineations, which have oftenbeen contested. This indicates that soft planning as such is not attached to a certain type of space (i.e. soft or hard), but also that because soft planning is connected to the idea of competitive economic spaces, it requires re-negotiating the boundaries or tolerance of many spatial demarcations. These make both the region and its borders at least penumbral, if not soft/fuzzy.

Identity serves as an instrumental asset in soft planning, and the emphasis on soft planning seems to stress strategic and functional elements of identity over cultural ones. In general, however, identity was not particularly discussed in the interviews. Nevertheless, the process of demarcation and contested territoriality indicates that there is some awareness of functional and strategic identity in Barents. Also, a degree of cultural identity can be observed in Cascadia, as location outside the federal government's 'gaze' was thought to feed the cultural mindset and 'laid-back' lifestyle. In the Barents region the identity-making has been more attached to regionalization and bounding practices in the post-Cold War context, further underlining the strategic identity. Yet, as the idea of inclusiveness/exclusiveness is strong in the Barents region, cultural identity is presumably emerging there too. Much, naturally, depends on how the geopolitical situation develops and whether the 'big geopolitics' of states and the EU have an impact on the 'small geopolitics' in the Barents region. As the quotation above illustrates, there is some concern that co-operation might become more 
difficult, and the state borders between east and west harden. This indicates not only that geoeconomics and geopolitics have at times competing logics, but also that geopolitics do cross scales, and that micro- and macro-regionalism are to some extent inevitably interlinked. It also points out that nation-states are still 'shaping' much of the transnational regionalism in Europe.

According to Haughton et al. (2013) fuzzy boundaries help to create new cross-border identities, and the European Commission's focus on cross-border identities stems from the need to open up the debate on boundary problems, particularly in peripheral areas. In this sense, Cascadia works exactly this way, whereas - quite surprisingly - in Barents the long-term contestations about including North Karelia in the Barents region and the more general requirements of territorial symmetry indicate that territoriality is even unnecessarily exaggerated. However, when speaking of boundaries of supranational spaces, we need to distinguish between borders that 'frame' spaces and borders that cut across them. Supranational spaces such as Cascadia and Barents are framed and demarcated by the borders of subnational states and regions, with the borders of nation-states intersecting them. Thus, borders are typically harder inside the regions than around them. Hence, it might be useful in planning practices to soften the national borders that cross the regions in order to boost supranational identities, and at the same time to 'solidify' the softer borders that frame the regions in order to turn the supranational space into a distinctive spatial entity/unit that has an identity and can be identified with.

The problem in doing this is, however, that there are usually relatively strong national identities inside the region, which makes supranational identity-work (and planning) complex and contested. As Hettne and Söderbaum (2000) state, it is the territorial states who have monopolized external relations and decided who is 'friend or foe', and this has meant much discouragement of regional consciousness beyond the state. Thus, "the people of the separate nation-states are not likely to have much knowledge of or mutual trust in each other, much less a shared identity" (p. 463). This is to say that states have not been bypassed as key territorial frameworks of identification, primarily due to their longer histories in terms of spatial socialization and identity-politics (based on distinctively territorial manifestations). Also, as regionalism is an extremely complex and dynamic process made up of multiple logics, the logics of identity are often downplayed in favour of more concrete ones such as the logics of security or economic transformation (Hurrell 2005).

Relatedly, it is fair to say that supranational regions face a 'burden of expectations': they are expected not only to become economic engines but also to help reduce political tensions and to foster common identity, among other things. As they are facing these expectations, they are also expected to operate much like every other region, albeit in collaboration with region(s) on the other side of the border which may be organized and governed very differently. At best things can work smoothly, but at worst supranational regionalism contributes to a regional 'mishmash' and is maintained by regional elites with rather opportunistic motives (Popescu 2012).

\section{Conclusions}

This paper has discussed how supranational identities are connected to planning practices and contribute to the regionalization of supranational space. Three notions rise above the rest. First, identity as such is rarely (if ever) touched on, although it is acknowledged that some idea of supranational spatial consciousness beyond the nation-state exists. As one advocate in Cascadia put 
it, "people think of themselves as part of some kind of a region that just goes beyond just their state or their province, that makes this part of North America different from the other parts of North America". A modicum of supranational consciousness can be identified in the Barents region too, and although relatively weak and rather top-down in origin, it is recognized that it has some significance also in planning.

Second, although not discussed as such, the idea of supranational identity is clearly embedded in governance structures as well as in territory-network interplay. This means that identity is something that is manifested to central authorities (European Union, Washington DC, etc.) through processes and networks that take place within the region. There is also a sense of 'otherness' which feeds into the idea of regional identity. This sense is, nevertheless, only partially based on bounded space. Identity is often attached to boundaries (as in Barents), but some kind of an idea of regional uniqueness and identification is also possible in very loosely, contextually and variably manifested regions such as Cascadia. Thus, while identity is typically based on boundaries and territorial thinking, it can also emerge as a result of networks. This underlines the interplay of territories and networks, but also the fact that no network is aspatial. Similarly, soft planning and soft spaces do not necessarily mean that regional identity is absent. Instead, in soft planning identity might simply be more attached to instrumental institutions and be understood as primarily functional or strategic.

Third, as planning institutions tend to be instrumental by default and as they contribute to strategic and functional identities, planning is not exclusively about making us-and-them divisions. Rather, it is more about framing regions (for promotion and to secure funding) and about drawing and highlighting (fuzzy) growth corridors as well as linkages between the nodes and hubs. This is, of course, typical of relational thinking and soft planning, through which new regions in particular are developed (Allmendinger et al. 2016).

In general, despite its role as a 'soft tool', supranational identity is not something that is very actively or consciously developed or utilized in planning, especially in its cultural definition. The interviewed advocates did not see regional identity as pointless, but were rather oblivious as to how and why it should be underlined: they did not contemplate supranational identity as highly strategic but regarded it as a 'by-product' and therefore not significantly relevant. This is not to say that strategic identity was totally absent, however. As mentioned, it is connected to mapping and delineating practices, which are typically connected to branding practices. Branding is one way to present the region as a cohesive spatial unit to those who allocate funding (Zimmerbauer 2016). It is advantageous to illustrate the region as a bounded space with a distinctive identity in order to secure the continuity of both region and regional (planning) institutions.

Like identity, the question of agency is multifaceted. Both in Cascadia and Barents the key players are the instrumental institutions, yet there are also some (weak) signs of identity-providing activities. Due to its origins as a bioregion, some of these institutions in Cascadia are NGOs and associations. These institutions, contrary to the more instrumental ones such as PNWER, seem to be more eager to ponder the location of the borders of the supranational region, and are more concerned about the various territorial delineations. In Barents, this kind of grassroots activity is less common, and the idea of bounded space is mostly promoted by the institutionalized planning and development system. This explains why territorial transformation (i.e. the inclusion of new sub- 
national regions) has been a contested process amongst spatial planning circles. This also suggests that despite the idea(l) of soft planning and soft spaces, and the emphasis on networks across borders, the actors and institutions are unable to escape the territorial structures.

Supranational 'identity-work' and planning practices are linked to cross-border regionalization processes and contemporary ideas about (new)regionalism. However, although one of the results of new regionalism has been "a literature on the end of territory, the borderless world and the network society" (Keating 2008b, p. 69), supranational spaces are constituted largely through territorial politics and discourses. Yet, territories are not as enclosing or fixed as they once were, but appear more in relation with each other in the intertwined processes of institutionalization and deinstitutionalization. This has contributed to the current situation of many simultaneous regionalisms and multiple overlapping regional systems, partly complementing and partly competing with each other. This underlines further that regions are processes and social constructions, some, naturally, more 'solidified' and lasting than others. Time will tell if it is North Calotte, Barents, Pacific Northwest, Cascadia or some other manifestation of a region that will be on the forefront in the future.

Allmendinger, P., Chilla, T. and Sielker, F. (2014) Europeanizing territoriality-towards soft spaces? Environment and planning A, 46.11, 2703-2717. doi:10.1068/a130037p.

Allmendinger, P., Haughton, G. and Shepherd, E. (2016). Where is planning to be found? Material practices and the multiple scales of planning. Environment and Planning C: Government and Policy, Vol. 34, 38-51. doi:10.1177/0263774X15614178.

Anderson, B. (1991). Imagined Communities. Reflections on the Origin and Spread of Nationalism. London, Verso.

Barentsinfo (2016). http://www.barentsinfo.org/Barents-region/Cooperation; http://www.barentsinfo.org/Barents-region (accessed 14.12.2016).

Blatter J. (2004). From 'spaces of place' to 'spaces of flows'? Territorial and functional governance in cross-border regions in Europe and North America. International journal of urban and regional research 28:3, 530-548.

Brunet-Jailly E. (2008). Cascadia in Comparative Perspectives: Canada-U.S. relations and the Emergence of cross-border regions. Canadian Political Science Review Vol 2(2), 104-124.

Cowen, D. and Smith, N. (2009). After geopolitics? From the geopolitical social to geoeconomics. Antipode, 41:1, 22-48.

Deas I. and Lord A. (2006). From new regionalism to an unusual regionalism? The emergence of non-standard regional spaces and lessons for the territorial reorganization of the state. Urban studies 43:10, 1847-1877. doi:10.1080/00420980600838143.

Elenius, L. (2015) (Chief-Editor). The Barents Region. A transnational history of subarctic Northern Europe. Pax Forlag, Oslo. 
Fawn R. (2009). 'Regions' and their study: wherefrom, what for and whereto? Review of International Studies, 35, 5-34. doi:10.1017/S0260210509008419.

Hall P. (2008). Opportunities for democracy in cross-border regions? Lessons from the Øresund region. Regional Studies 42:3, 423-435.

Hasanat W, (2012). A unique arrangement of soft-law cooperation in the Barents Region. In M. Tennberg (Ed.) Politics of Development in the Barents Region. Lapland University Press, Rovaniemi, 66-84.

Haughton G, Allmendinger P, Oosterlynck S, (2013). Spaces of neoliberal experimentation: soft spaces, postpolitics and neoliberal governmentality. Environment and Planning A:45, 217-234.

Haughton, G. Allmendinger, P. (2015). Fluid Spatial Imaginaries: Evolving Estuarial City-regional Spaces. International journal of urban and regional research. DOI: 10.1111/1468-2427.12211.

Hettne, B. and Söderbaum, F. 2000. Theorizing the rise of regionness. New political economy, 5:3, 457-472. doi: 10.1080/713687778.

Houtum, H. van and Lagendijk, A. (2001). Contextualising Regional Identity and Imagination in the Construction of Polycentric Urban Regions: The Cases of the Ruhr Area and the Basque Country. Urban Studies, 38 (4), 747-767. doi:10.1080/00420980120035321.

Hurrell, A. (2005). The regional dimension in International Relations theory. In Farrell, M., Hettne, B. and Van Langenhove, L. (Eds.). Global Politics of Regionalism. Pluto press, London, 21-37.

Jones, M and MacLeod, G. (2004). Regional spaces, spaces of regionalism: territory, insurgent politics and the English question. Transactions of the Institute of British Geographers, Vol. 29, Issue 4, 433-452.

Keating, M. (2008a). A quarter century of the Europe of the regions. Regional and Federal Studies, 18:5, 629-635. doi: 10.1080.13597560802351630.

Keating, M. 2008b. Thirty years of territorial politics. West European Politics, 31:1-2, 60-81. doi: $10.1080 / 01402380701833723$.

Keating, M. 2014. Introdution: rescaling interests. Territory. politics, governance, 2:3, 239-248. DOI: $10.1080 / 21622671.2014 .954604$.

Kjølberg A. (1994). The Barents Region as a European security-building concept. In Stokke O. and Tunander O. (Eds.) The Barents Region. Cooperation in Arctic Europe. Sage, London, 187-199.

Metzger, J. (2013) Raising the regional Leviathan: a relational-materialist conceptualization of regions-in-becoming as publics-in-stabilization. International Journal of Urban and Regional Research 37:4, 1368-1395. doi:10.1111/1468-2427.12038.

Metzger, J., Allmendinger, P. and Oosterlynck, S. (eds.). (2015). Planning against the political. Democratic deficits in European territorial governance. Routledge, Oxon. 
Moisio, S. \& Paasi, A. (2013). From Geopolitical to Geoeconomic? The Changing Political Rationalities of State Space, Geopolitics, 18:2, 267-283, doi:10.1080/14650045.2012.723287.

Olesen, K (2011). Strategic spatial planning in transition - a case study of Denmark. Aalborg University, Aalborg, Akprint.

Paasi A. (1986). The institutionalization of regions: a theoretical framework for understanding the emergence of regions and the constitution of regional identity. Fennia 164:1, 105-146.

Paasi, A. (1996). Territories, Boundaries, and Consciousness: The Changing Geographies of the Finnish-Russian Boundary. New York: J. Wiley \& Sons.

Paasi, A. and Zimmerbauer, K. (2016). Penumbral borders and planning paradoxes: Relational thinking and the question of borders in spatial planning. Environment and Planning A 48, 75-93. doi: 10.1177/0308518X15594805.

Painter, J. (2010). Rethinking Territory. Antipode. Vol. 42(5), 1090-1118. doi:10.1111/j.14678330.2010.00795.x.

Perkmann M. (2007). Construction of new territorial scales: a framework and case study of the Euregio cross-border region. Regional Studies 41:2, 253-266.

Popescu, G. (2012). Bordering and Ordering the twenty-first century. Understanding borders. Rowman and Littlefield, Lanham.

Slocum, N. and Van Langenhove, L. (2005). Identity and regional integration. In Farrell, M., Hettne, B. and Van Langenhove, L. (Eds.). Global Politics of Regionalism. Pluto press, London, 137-154.

Smith, P. J. (2008). Branding Cascadia: Considering Cascadia's conflicting conceptualizations who gets to decide? Canadian political science review, Vol. 2:2, 57-83.

Sparke, M. (2000). Excavating the future in Cascadia: Geoeconomics and the imagined geographies of a cross-border region. BC Studies, 127, 5-44.

Sparke, M. (2005). In the space of theory. Postfoundational geographies of the nation-state. Minneapolis, university of Minnesota press.

Svensson B. (1998). Politics and business in the Barents region. Fritzes, Stockholm.

Söderbaum, F. (2005). Exploring the links between micro-regionalism and macro-regionalism. In Farrell, M., Hettne, B. and Van Langenhove, L. (Eds.). Global Politics of Regionalism. Pluto press, London, 87-103.

Söderbaum, F. (2016). Rethinking regionalism. Palgrave, London.

Tewdwr-Jones, M., Allmendinger, P., (2006). Territory, Identity and Spatial Planning. Routledge, London. 
Walsh, C., Jacuniak-Suda, M., Knieling, J. and Othengrafen, F. (2012). Soft Spaces in Spatial Planning and Governance: Theoretical Reflections and Definitional Issues. Regional Studies conference proceeding.

http://www.regionalstudies.org/uploads/funding/conferences/presentations/european-conference2012/presentations/walsh-et-al.pdf (accessed 3.2.2016).

Zimmerbauer, Kaj (2013). Unusual regionalism in northern Europe. Barents region in the making. Regional Studies, 47:1, 89-103. doi:10.1080/00343404.2011.644236.

Zimmerbauer, K. (2014). Constructing peripheral cross-border regions in planning: territorynetwork interplay in the Barents region. Environment and Planning A, Vol. 46, 2718 - 2734. doi:10.1068/a140001p.

Zimmerbauer, K. (2016). Constructing supranational identities through branding: thick and thin region-building in the Barents and Ireland-Wales. European Urban and Regional Studies July 2016 23: 322-337. doi:10.1177/0969776413512842. 